\title{
Bladder Cancer TNM Finding v6
}

National Cancer Institute

\section{Source}

National Cancer Institute. Bladder Cancer TNM Finding v6. NCI Thesaurus. Code C61227.

A finding about one or more characteristics of bladder cancer, following the rules of the

TNM AJCC v6 classification system. 